\title{
Naringenin modulates skeletal muscle differentiation via estrogen receptor $\alpha$ and $\beta$ signal pathway regulation
}

\author{
Marco Pellegrini • Pamela Bulzomi • \\ Paola Galluzzo $\cdot$ Marco Lecis $\cdot$ Stefano Leone \\ Valentina Pallottini $\cdot$ Maria Marino
}

Received: 20 March 2014/ Accepted: 29 July 2014/Published online: 26 August 2014

(c) Springer-Verlag Berlin Heidelberg 2014

\begin{abstract}
Several experiments sustain healthful benefits of the flavanone naringenin (Nar) against chronic diseases including its protective effects against estrogen-related cancers. These experiments encourage Nar use in replacing estrogen treatment in post-menopausal women avoiding the serious side effects ascribed to this hormone. However, at the present, scarce data are available on the impact of Nar on E2-regulated cell functions. This study was aimed at determining the impact of Nar on the estrogen receptor (ER $\alpha$ and $\beta$ )-dependent signals important for $17 \beta$-estradiol (E2) effect in muscle cells (rat L6 myoblasts, mouse C2C12 myoblasts, and mouse skeletal muscle satellite cells). Dietary relevant concentration of Nar delays the appearance of skeletal muscle differentiation markers (i.e., GLUT4 translocation, myogenin, and both fetal and slow MHC isoforms) and impairs E2 effects specifically hampering $\mathrm{ER} \alpha$ ability to activate AKT. Intriguingly, Nar effects are specific for E2-initiating signals because IGF-Iinduced AKT activation, and myoblast differentiation markers were not affected by Nar treatment. Only 7 days after Nar stimulation, early myoblast differentiation markers (i.e., myogenin, and fetal MHC) start to be accumulated in myoblasts. On the other hand, Nar stimulation
\end{abstract}

Electronic supplementary material The online version of this article (doi:10.1007/s12263-014-0425-3) contains supplementary material, which is available to authorized users.

M. Pellegrini - P. Bulzomi · P. Galluzzo - M. Lecis · S. Leone · V. Pallottini · M. Marino

Department of Sciences, Biomedical and Technology Science Section, University Roma Tre, Viale G. Marconi 446,

00146 Roma, Italy

M. Marino $(\bowtie)$

INBB-National Laboratory of Endocrine Disruptors, Roma, Italy

e-mail: m.marino@uniroma3.it activates, via ER $\beta$, the phosphorylation of p38/MAPK involved in reducing the reactive oxygen species formation in skeletal muscle cells. As a whole, data reported here strongly sustain that although Nar action mechanisms include the impairment of $\mathrm{ER} \alpha$ signals which drive muscle cells to differentiation, the effects triggered by Nar in the presence of ER $\beta$ could balance this negative effect avoiding the toxic effects produced by oxidative stress.

Keywords Estrogen - Estrogen receptors - Naringenin Signal transduction - Skeletal muscle differentiation

\section{Introduction}

In recent years, plant-derived polyphenols, in particular flavonoids, deserved particular attention being associated with healthful benefits against chronic diseases (Shulman et al. 2011; Crozier et al. 2009). Examples of such polyphenols are resveratrol in red wine and epigallocatechin in green tee (Bengmark et al. 2009). One of the most abundant bioactive flavonoids is the glycoside naringin, responsible for the bitter taste in grapefruit, which is hydrolyzed to naringenin (4,5,7-trihydroxy-flavanone-7 rhamnoglucoside, Nar) by the gut flora prior to being absorbed by enterocytes. Naringenin protective effects have been widely studied: antioxidant effects (Renugadevi and Prabu 2009), modulation of cytochrome P450 detoxification enzymes (Huong et al. 2006), modulation of plasma cholesterol levels (Jeon et al. 2007), and antihyperglycemic effects (Jung et al. 2004) have been reported. In addition, several experimental data support anticarcinogenic and pro-apoptotic effects of Nar in numerous types of cancer (Arul and Subramanian 2013; Meiyanto et al. 2012; Weng and Yen 2012). Most of these effects have 
been obtained by using variable Nar concentrations ranging from 1 to $100 \mu \mathrm{M}$. We recently reported that Nar concentrations (1-10 $\mu \mathrm{M})$, achievable in human plasma after a meal rich in flavonoids (i.e., tomatoes, oranges, and grapefruit juice typical of Mediterranean diet), exert protective pro-apoptotic effects against estrogen-related cancers (Galluzzo and Marino 2006; Bulzomi et al. 2012, 2010). Nar binds to both estrogen receptors (i.e., ER $\alpha$ and ER $\beta$ ) (Kuiper et al. 1998; Bulzomi et al. 2012) and acts as a mimetic of $17 \beta$-estradiol (E2), the most active among estrogens, activating a pro-apoptotic cascade in the presence of ER $\beta$ subtype (Totta et al. 2004; Galluzzo and Marino 2006; Marino et al. 2012). On the other hand, Nar selectively impairs the membrane-initiating signals of ER $\alpha$ subtype important for cell cycle progression (Virgili et al. 2004; Galluzzo and Marino 2006; Galluzzo et al. 2008; Marino et al. 2012).

As a whole, these data suggest that Nar could potentially replace the actions of E2. However, E2 effects in mammals include the regulation of growth and differentiation of several organs and tissues influencing the whole homeostasis maintenance in both male and female organisms (Thomas and Gustafsson 2011). Thus, Nar ability to interfere with ER activities raises some concerns on the putative unhealthy side effects of this flavonoid. In addition, $E R \alpha$ and $E R \beta$ could be co-expressed within the same organ rendering very difficult to predict the Nar interference on E2 effects. An example is represented by differentiating skeletal muscle.

Although adult skeletal muscle is a stable tissue, it possesses the remarkable ability to rapidly recover and regenerate following injury (Thomas and Gustafsson 2011; Hawke and Garry 2001). In response to injury, undifferentiated satellite cells are activated from a quiescent state and proliferate as myoblasts. Myoblasts, in turn, are withdrawn from the cell cycle and differentiate re-expressing myogenic regulatory factors (MRFs, namely MyoD, Myf5, myogenin, and MRF4) as well as embryonic myofibrillar genes (e.g., the fetal isoform of myosin heavy chain, $f M H C$ ). Finally, differentiated myoblasts fuse to form the multinucleated mature muscle fibers, thus contributing to skeletal muscle regeneration (Hawke and Garry 2001; Trapani et al. 2012).

Several endocrine factors, including sex steroid hormones, can influence muscle cell differentiation throughout life via their cognate receptors. In particular, many studies have demonstrated sex differences in skeletal muscle response to injury and in the indices of skeletal muscle damage, inflammation, and repair that are largely attributable to E2 (Bar et al. 1988; McClung et al. 2006). Skeletal muscle expresses both ERs, and in rodents, ER $\beta$ is the predominant subtype (Barros and Gustafsson 2011; Galluzzo et al. 2009). ER $\beta$ seems to participate to the E2- induced skeletal muscle regeneration after injury even if a suppressive role on glucose transporter (GLUT4) expression has been evidenced (Velders et al. 2012; Barros and Gustafsson 2011). On the other hand, we recently reported that E2 only requires ER $\alpha$-dependent rapid p38/MAPK and PI3 K/AKT activation to induce L6 myoblast differentiation (Galluzzo et al. 2009). At the present, the impact of Nar on ER $\alpha$-mediated skeletal muscle cell differentiation is unknown. This study was aimed at determining the impact of the flavonoid Nar on E2-induced differentiation in skeletal muscle cells. Rat L6 myoblasts, mouse C2C12 myoblasts, and mouse satellite cells were used as experimental models.

\section{Materials and methods}

\section{Reagents}

$17 \beta$-Estradiol (E2), naringenin (Nar), insulin-like growth factor I (IGF-I), actinomycin, cycloheximide, gentamicin, penicillin, 'Dulbecco's modified Eagle's medium' (DMEM) (without phenol red), F-10 Ham (N6908), charcoal-stripped fetal calf serum, and the palmitoyl acyltransferase (PAT) inhibitor 2-bromohexadecanoic acid (2$\mathrm{Br}$ ) were purchased from Sigma-Aldrich (St. Louis, MO, USA). The ER inhibitor ICI 182,780, the ER $\alpha$ selective agonist, PPT (4,4', $4^{\prime \prime}$-(4-propyl-[1H]-pyrazole-1,3,5triyl)trisphenol), the ER $\beta$ selective agonist, DPN (2,3bis(4-hydroxyphenyl)-propionitrile), and the ER $\beta$ selective antagonist, THC $((R, R)-5,11$-diethyl-5,6,11,12-tetrahydro2,8-chrysenediol) were obtained from Tocris (Ballwin, MO, USA). The AKT inhibitor, the extracellular regulated kinase (ERK) inhibitor, PD 98059, and the p38 inhibitor, SB 203580, were obtained from Calbiochem (San Diego, CA). Bradford protein assay was obtained from Bio-Rad Laboratories (Hercules, CA, USA). The antiphospho-ERK, anti-AKT, anti-ERK, anti-ER $\alpha$ M20 ( $N$-terminus), antiER $\beta$ H150, and anticaspase-3 antibodies were obtained from Santa Cruz Biotechnology (Santa Cruz, CA, USA). The antiglucose transporter type 4 (Glut-4), antimyogenin, and antifetal myosin heavy chain (fetal MHC) were purchased from Abcam (Cambridge, UK). Antifast MHC MY32 and antislow MHC NOQ7.5.4D were purchased from Sigma-Aldrich (St. Louis, MO, USA). Anti- $\beta$-tubulin was purchased from MP Biomedicals (Solon, OH, USA). The polyclonal antiphospho-AKT, antiphospho-p38, and antip38 antibodies were purchased from New England Biolabs (Beverly, MA, USA). The CDP-Star, chemiluminescence reagent for Western blot was obtained from NEN (Boston, MA, USA). All the other products were from SigmaAldrich (St. Louis, MO, USA). Analytical or reagent grade products, without further purification, were used. 
Cell culture and cell cycle analysis

Rat myoblast L6 cells (ATCC, Manassas, VA) and mouse myoblasts C2C12 (a generous gift of Prof. Daniela Caporossi, IUSM, Rome Italy) were routinely grown in $5 \%$ $\mathrm{CO}_{2}$ in phenol red-free DMEM medium containing $10 \%$ (v/v) charcoal-stripped fetal calf serum, L-glutamine $(2.0 \mathrm{mM})$, gentamicin $(10.0 \mu \mathrm{g} / \mathrm{ml})$, and penicillin $(100.0 \mathrm{U} / \mathrm{ml})$. Cells were passaged every 2 days. Mouse adult primary satellite cells (a generous gift of Dr. Marco Crescenzi, ISS, Rome, Italy) were grown on gelatin-coated dishes in $77 \%$ nutrient mixture F-10 Ham with gentamicin $(10.0 \mu \mathrm{g} / \mathrm{ml})$, and penicillin $(100.0 \mathrm{U} / \mathrm{ml}), 20 \%$ fetal bovine serum, $3 \%$ chicken embryo extract (prepared in Hank's Balanced Solution), and $2.5 \mathrm{ng} / \mathrm{ml}$ basic fibroblast growth factor (Peprotech, Rocky Hill, NJ).

For differentiation, satellite cells were seeded at high density $\left(2.5 \times 10^{5}\right)$ in gelatine-coated $35 \mathrm{~mm}$ dishes, and after cell adhesion, growth medium was replaced with DMEM with gentamicin $(10.0 \mu \mathrm{g} / \mathrm{ml})$, penicillin $(100.0$ $\mathrm{U} / \mathrm{ml}$ ), and $10 \%$ fetal bovine serum. Medium was changed every $24 \mathrm{~h}$ (Trapani et al. 2012). L6 and C2C12 undifferentiated myoblasts were treated with differentiation medium containing $2 \%(\mathrm{v} / \mathrm{v})$ charcoal-stripped fetal calf serum; myotubes were obtained 7 day after serum concentration reduction (Galluzzo et al. 2009).

In differentiation, medium cells were simultaneously treated either with vehicle (ethanol/PBS 1:10, v/v) or with different E2 concentrations or different concentration of Nar or PPT (final concentration, $10 \mathrm{nM}$ ) or DPN (final concentration, $10 \mathrm{nM}$ ) or IGF-I (final concentration, $100 \mathrm{ng} / \mathrm{ml}$ ) or T (final concentration, $1 \mathrm{nM}$ ) or DHT (final concentration, $1 \mathrm{nM}$ ). Cells were harvested $6,24,48$, and $72 \mathrm{~h}$ or 7 days after treatment with differentiation medium. When indicated, the antiestrogen ICI 182,870 (final concentration $1 \mu \mathrm{M}$ ), the AKT inhibitor (final concentration $1 \mu \mathrm{M}$ ), the p38 inhibitor, SB 203580 (final concentration $5 \mu \mathrm{M}$ ), and the ER $\beta$ inhibitor, THC (final concentration $1 \mu \mathrm{M})$ were added $30 \mathrm{~min}$ before E2 or Nar or IGF-I administration.

L6 myoblasts were harvested with trypsin 24,48 , and $72 \mathrm{~h}$ after treatment and fixed with $1 \mathrm{ml}$ ice-cold $70 \%$ ethanol and subsequently stained with $2 \mathrm{mg} / \mathrm{ml}$ DAPI/PBS solution. The fluorescence of DNA was measured with DAKO Galaxyflow cytometer equipped with HBO mercury lamp, and the percentage of cells present in sub-G1 phase was calculated using FloMax (c) Software.

Measurements of reactive oxygen species (ROS)

L6 myoblasts were grown to $\sim 70 \%$ confluence, harvested, and then re-suspended in PBS with $10 \mu \mathrm{M}$ dichlorodihydrofluorescein diacetate (DCF; Molecular Probes, Eugene,
OR, USA) for $30 \mathrm{~min}$ at $37{ }^{\circ} \mathrm{C}$ in the dark. After additional $30 \mathrm{~min}$, to allow the equilibrium, the fluorescence was measured under continuous gentle magnetic stirring at $37{ }^{\circ} \mathrm{C}$ in a PerkinElmer LS-50B spectrofluorimeter. Excitation wavelengths were set at $498 \mathrm{~nm}$ and emission at $530 \mathrm{~nm}$, respectively. Cells were treated with $600 \mu \mathrm{M} \mathrm{H}_{2} \mathrm{O}_{2}$ (final concentration) in the presence of either E2 (final concentration, $10 \mathrm{nM}$ ) or Nar (final concentration, $1 \mu \mathrm{M}$ ) or vehicle or PPT (final concentration, $10 \mathrm{nM}$ ) or DPN (final concentration, $10 \mathrm{nM}$ ) for $15 \mathrm{~min}$, and fluorescence was registered as arbitrary unit. In some experiments, the p38 inhibitor, SB 203580 (final concentration $5 \mu \mathrm{M}$ ), and the ER $\beta$ inhibitor, THC (final concentration $1 \mu \mathrm{M}$ ) were added 30 min before E2 or Nar or IGF-I administration.

\section{Protein analysis}

Protein profiles were analyzed by Western blotting as previously described (Bulzomi et al. 2012). In some experiments, cells were homogenized by using Teflon pestle homogenizer; homogenates were centrifuged at $1,000 \times g$ for $10 \mathrm{~min}$ to pellet the nuclear fraction. Membrane-rich fractions were obtained by centrifuging the supernatants at $100,000 \times g$ for $30 \mathrm{~min}$. Proteins from membrane-rich fraction and from total lysate were then solubilized as described above (Galluzzo et al. 2009). Briefly, $20 \mu \mathrm{g}$ of protein from lysates were resolved by $7 \%$ SDS-PAGE at $100 \mathrm{~V}$ for $60 \mathrm{~min}$. The proteins were subsequently electrophoretically transferred to nitrocellulose for $90 \mathrm{~min}$ at $100 \mathrm{~V}$. The nitrocellulose membrane was blocked at room temperature with $3 \%$ BSA in Trisbuffered saline (138 mM NaCl, $27 \mathrm{mM} \mathrm{KCl}, 25 \mathrm{mM}$ Tris$\mathrm{HCl}, 0.05 \%$ Tween-20, $\mathrm{pH}$ 6.8) and probed at $4{ }^{\circ} \mathrm{C}$ overnight with primary antibodies followed by Trapani et al. (2012) incubation for $1 \mathrm{~h}$ with secondary antibodies. The nitrocellulose membrane was probed and then reprobed with anti- $\beta$-tubulin or anticaveolin- 1 antibodies to normalize total lysate or membrane fractions, respectively. Bound antibodies were visualized using enhanced chemoluminescence detection. All images derived from Western blotting were analyzed with ImageJ (NIH, Bethesda, MD) software for Windows. Each reported value was derived from the ratio between arbitrary units obtained by the protein band and the respective tubulin or caveolin-1 band.

Statistical analysis

Data are expressed as mean $\pm \mathrm{SD}$. The difference in parameters was statistically tested for significance with one-way ANOVA followed by Tukey-Kramer post test using GraphPad Instat3 (GraphPad software, Inc., La Jolla, CA) software for Windows. $P<0.05$ was considered statistically significant. 
Fig. 1 Time-course of E2 and Nar effect on differentiation markers in L6 cells. L6 cells were grown in the differentiation medium containing $2 \%$ serum. Western blot analysis of vehicle (DMSO:PBS 0.1:1), E2 $\left(10^{-8} \mathrm{M}\right)$, and Nar $\left(10^{-6} \mathrm{M}\right)$ treatment on myogenin (a), Fetal MHC (b) levels and related densitometric analyses (c). d Vehicle, E2 and Nar effect on GLUT-4 plasma membrane translocation ( d) and related densitometric analysis. The amount of proteins was normalized by comparison with tubulin (a and b) or cav-1 (d) levels. Data are the mean of five different

experiments \pm SD. $* P<0.001$ was calculated with ANOVA followed by Tukey-Kramer post test with respect to the vehicle-treated samples

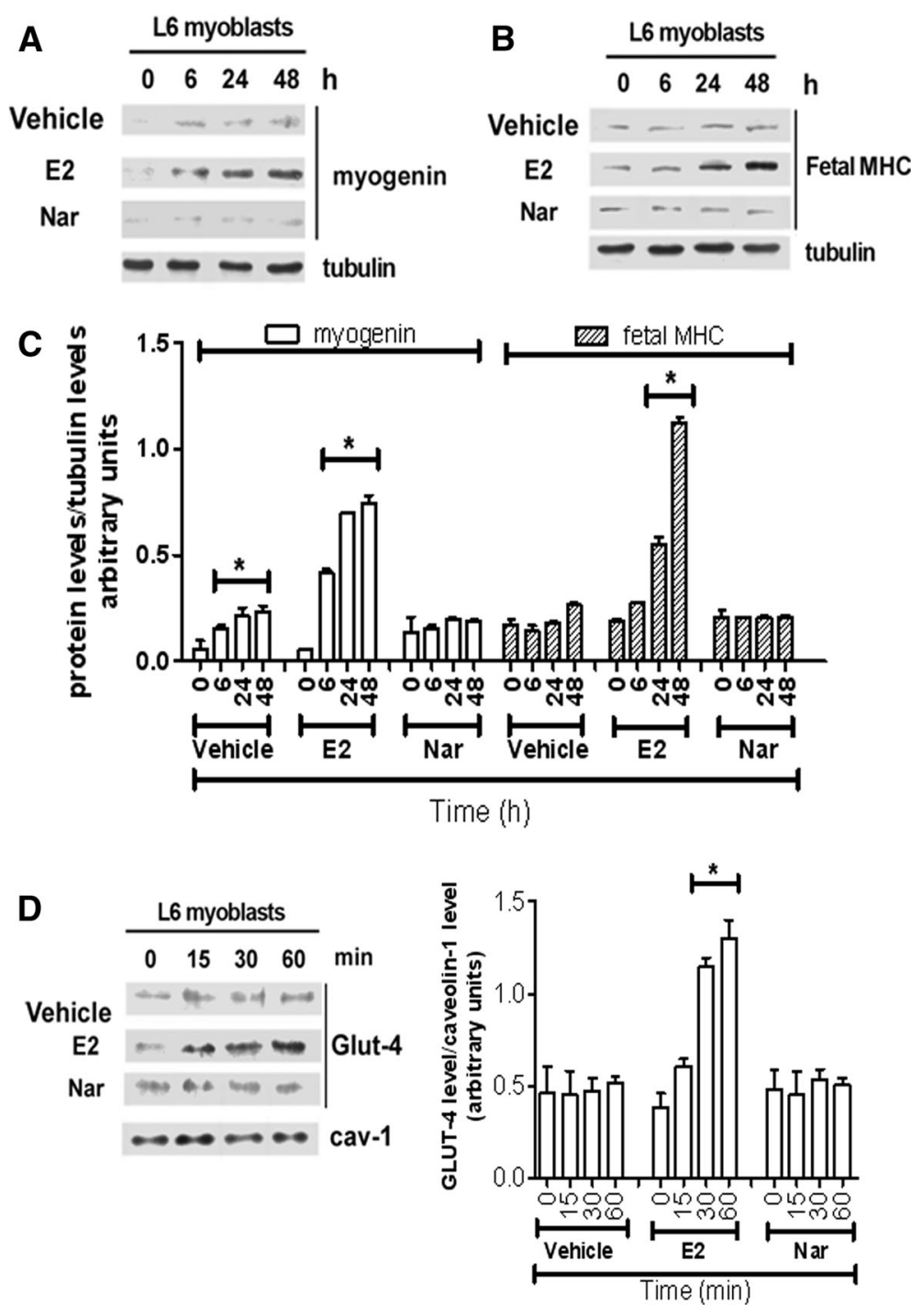

\section{Results}

Nar effects on skeletal muscle cell differentiation markers

As expected, ER $\beta$ is the predominant receptor subtype in growing rat L6 myoblasts (Galluzzo et al. 2009). However, the induction of myoblast differentiation by serum withdrawal is paralleled by an increase of ER $\alpha$ levels, which remain high until $72 \mathrm{~h}$ (supplemental figure 1A). In spite of the variation in the ER subtype levels, neither E2 (10 nM) nor Nar $(1 \mu \mathrm{M})$ modifies the distribution of myoblasts in the cell cycle at any of the tested times (supplemental figure 1B) or activate the cleavage of caspase-3, the effector of apoptosis (17 kDa band, supplemental figure $1 \mathrm{C}$ ) until $72 \mathrm{~h}$ after serum reduction. These data sustain that none of the tested compounds modify myoblast proliferation or apoptosis. On the other hand, just $6 \mathrm{~h}$ after serum removal, the levels of myogenin (Myo, a wellknown marker of myoblast differentiation) (Hawke and Garry 2001; Trapani et al. 2012) increase, and the levels of this protein are further enhanced in myoblasts treated with $10 \mathrm{nM}$ E2 (Fig. 1a, c). In line with the differentiative effect of E2 already reported in growing L6 cells (Galluzzo et al. 2009), $24 \mathrm{~h}$ after serum removal the hormone, the level of the fetal isoform of myosin heavy chain (MHC, a contractile protein marker of skeletal muscle differentiation) doubled over the control (Fig. 1b, c). In contrast, Nar stimulation did not modified Myo or fetal MHC level up to $48 \mathrm{~h}$ of stimulation (Fig. 1b, c). A similar effect was reported also for the glucose transporter GLUT-4, a metabolic marker (Fig. 1d). Indeed, only E2 increased the translocation of GLUT-4 to the plasma membrane just 15 min after hormone treatment (Fig. 1d). The E2-induced increase of skeletal muscle differentiation (i.e., Myo and fetal MHC) and metabolism (i.e., GLUT-4) markers, after 
Fig. 2 Dose response effects of E2 and Nar effect on differentiation markers in L6 cells. a, b, and c, The typical western blots of E2 and Nar dose-dependent (ranging from $10^{-10}$ to $10^{-6} \mathrm{M}$ ) effects on myogenin, Fetal MHC levels ( $24 \mathrm{~h}$ of stimulation) and on GLUT-4 translocation to the plasma membrane (30 min of stimulation), respectively. d shows the related densitometric analyses. The amount of proteins was normalized by comparison with tubulin (a and b) or cav-1 (c) levels. Data are the mean of 3 different experiments \pm SD. ${ }^{*} P<0.001$ was calculated with ANOVA followed by TukeyKramer post test with respect to control samples
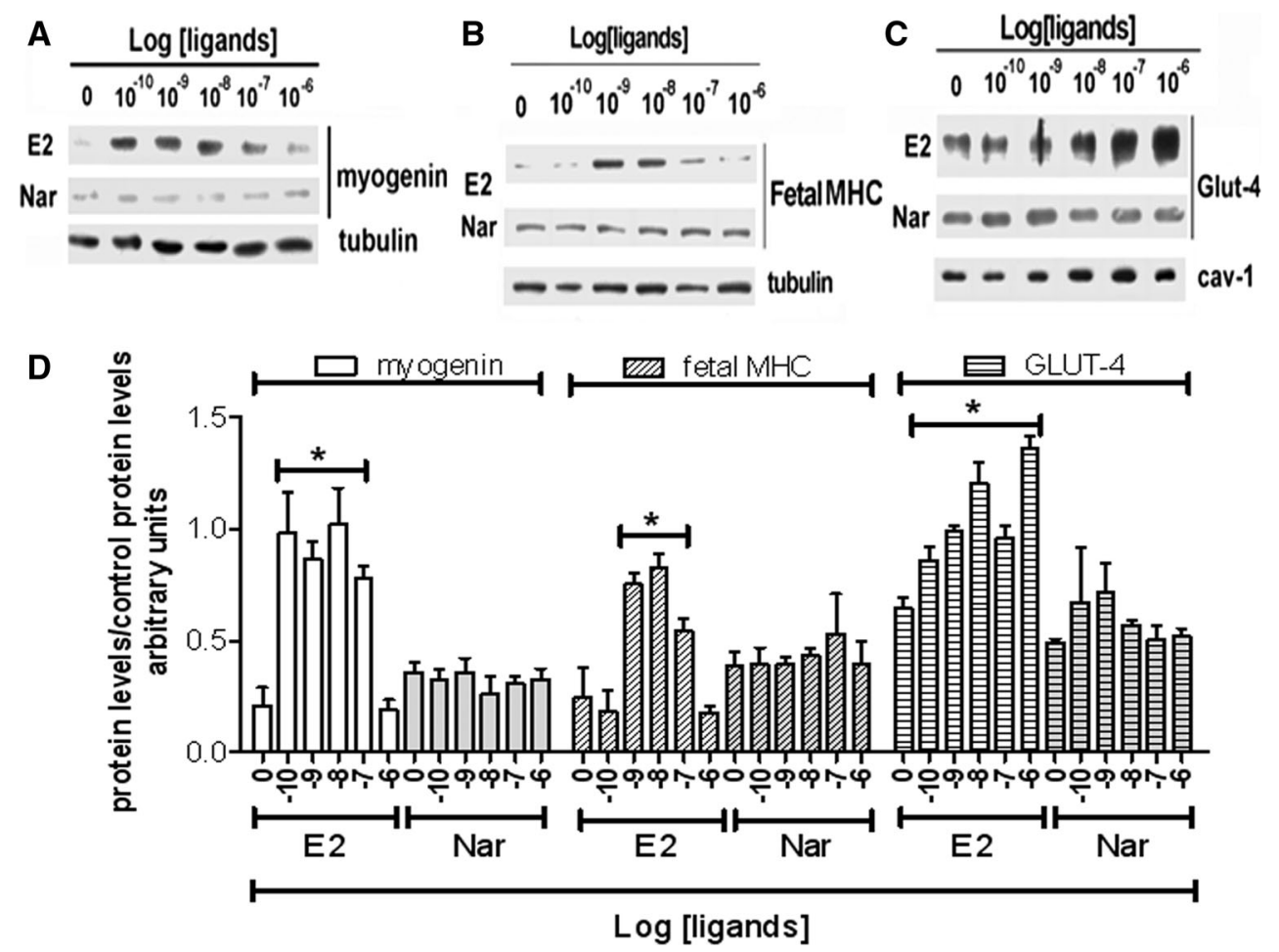

$48 \mathrm{~h}$ of stimulation, was dose-dependent with a maximum detected from $0.1 \mathrm{nM}$ to $10 \mathrm{nM}$ for Myo (Fig. 2a, d), $1 \mathrm{nM}$ to $10 \mathrm{nM}$ for fetal MHC (Fig. 2b, d), and $1 \mathrm{nM}$ to $1 \mu \mathrm{M}$ for GLUT-4 translocation (Fig. 2c, d), respectively. Notably, Nar had no effect either on Myo and fetal MHC levels or on GLUT-4 translocation at any of the tested concentrations (Fig. 2). However, Nar stimulation (0.1-10 $\mu \mathrm{M})$ in the presence of an E2 background (10 nM) completely reduced the hormone effects on differentiation marker levels (Fig. 3a, b) in L6 cells, suggesting that Nar could antagonize the E2 effects in rat L6 myoblasts.

This antagonistic effect of Nar was also confirmed in mouse satellite cells and C2C12 myoblasts. Satellite cells recapitulate several mechanisms of skeletal muscle regeneration and differentiation. Regenerating muscles initially express MHCs that are typical of developing muscle, such as fetal MHCs, but soon they start to express adult isoforms of MHCs (i.e., fast and slow MHC), which identify terminally differentiated myofibers (Zammit et al. 2006; Ciciliot and Schiaffino 2010). This MHC switch is a default program, which also occurs in the absence of the innervation (Ciciliot and Schiaffino 2010). Western blot analyses confirmed the presence of both ER subtypes in satellite cells (Supplemental figure 2A) and revealed that, after $24 \mathrm{~h}$ of differentiation stimuli, these cells present higher levels of Myo and fetal MHC (Supplemental figure 2B and 2C) with respect to L6 myoblasts (see Fig. 1). After $48 \mathrm{~h}$ of serum withdrawal, the levels of Myo and fetal MHC decreased to disappear $72 \mathrm{~h}$ after stimuli, with the contemporary increase of fast and slow MHC isoform levels (Supplemental figure 2B and 2C). Interestingly, E2 treatment (10 nM, $72 \mathrm{~h})$ specifically increased the slow MHC isoform without any effect on fast MHC isoform (Supplemental figure $2 \mathrm{~B}$ and $2 \mathrm{C}$ ). This E2 effect is mimicked by $10 \mathrm{nM}$ of ER $\alpha$ agonist PPT but not by the ER $\beta$ agonist DPN (10 nM) (Supplemental figure D) demonstrating that, like in L6 myoblasts (Galluzzo et al. 2009), ER $\alpha$ is the receptor subtype involved in $\mathrm{E} 2$ effects in satellite cells. Although Nar alone ( $1 \mu \mathrm{M}, 72 \mathrm{~h})$ did not exert any effect on the level of slow and fast MHC isoforms (Fig. 4a), Nar and E2 co-treatment impaired E2 effect on slow MHC level (Fig. 4a). Similar effect of Nar $(1 \mu \mathrm{M}, 48 \mathrm{~h})$ was reported in $\mathrm{C} 2 \mathrm{C} 12$ mouse myoblasts (Fig. 4b) sustaining the antagonistic role of this flavonoid in satellite cells and rat and mouse myoblasts.

As a whole, these data suggest that Nar delays the skeletal muscle differentiation marker appearance and acts as an E2 antagonist impairing the hormone-induced differentiative effects. This assumption prompted us to verify the long-term Nar and E2 effects on skeletal muscle differentiation markers. As expected from the data of satellite cells (Supplemental figure 2), E2 stimulation (10 nM, 7 days) of L6 myoblasts did not modify the level of either Myo or fetal MHC, although the hormone still increased slow MHC isoform. Intriguingly, a longer stimulation with Nar ( $1 \mu \mathrm{M}, 7$ days) significantly increased both early 

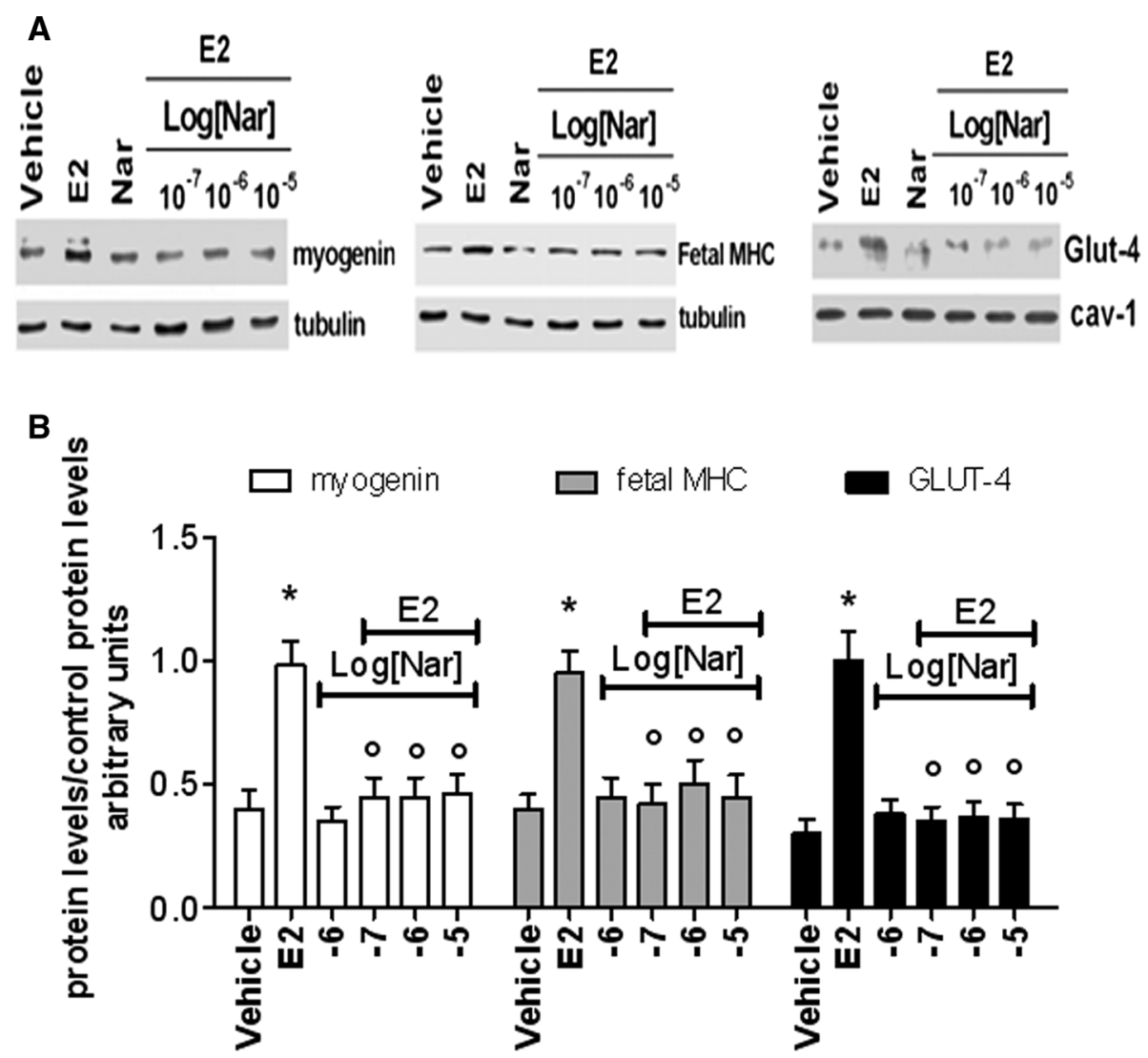

Fig. 3 Effect E2 and Nar coadministration on differentiation markers in L6 cells. L6 cell were maintained in differentiation medium (2\% serum) for $24 \mathrm{~h}$ (myogenin and Fetal MHC) or $30 \mathrm{~min}$ (GLUT-4) in the presence of either vehicle (DMSO:PBS $0.1: 1)$ or E2 $\left(10^{-8} \mathrm{M}\right)$ or $\operatorname{Nar}\left(10^{-6} \mathrm{M}\right)$ or different concentration of Nar (ranging from $10^{-7} \mathrm{M}$ to $\left.10^{-5} \mathrm{M}\right)$ in the presence of E2 background $\left(10^{-8} \mathrm{M}\right)$. a The typical western blot of myogenin and MHC levels, and GLUT-4 plasma

differentiation markers (i.e., Myo and fetal MHC) even in the presence of E2 (Fig. 5a) without any effect on the late differentiation marker (i.e., slow MHC), while this flavonoid still impaired E2-induced increase of slow MHC. The Nar-induced fetal MHC level requires ER being completely prevented by the pre-treatment with the pure ER inhibitor, ICI 182,870 (1 $\mu \mathrm{M})$ (Fig. 5b).

\section{Nar action mechanisms in L6 cells}

As previously reported (Galluzzo et al. 2009), E2-induced differentiation in proliferating L6 cells requires ER $\alpha$ mediated AKT and p38 MAPK activation, which, in turn, are necessary for the rapid GLUT-4 plasma membrane translocation and for Myo and fetal MHC increase. Here, we confirm that in differentiating L6 myoblasts, ER $\alpha$ is also necessary for the E2-induced rapid (15 min) activation of both AKT and p38, whereas the ER $\beta$ agonist, DPN, just activates p38 without any effect on AKT phosphorylation membrane translocation and $\mathbf{b}$ The related densitometric analyses. The amount of proteins was normalized by comparison with tubulin (myogenin and Fetal MHC) or cav-1 (GLUT-4) levels. Data are the mean of five different experiments \pm SD. $P<0.001$ was calculated with ANOVA followed by Tukey-Kramer post test with respect to vehicle-treated samples (asterisk) or to E2-treated samples (open circle)

(Supplemental figure 3). Thus, it is possible that the Nar effects in delaying differentiation rely on the inhibition of AKT and p38 activation. In order to verify this hypothesis, L6 cells were stimulated with Nar, E2 and IGF-I, a wellknown muscle trophic factor. As shown in Fig. 6a, b, both E2 and IGF-I rapidly increased (15 min) AKT phosphorylation, whereas Nar did not modify the phosphorylation status of this kinase, but this flavonoid specifically prevented the ability of E2 to activate AKT without any effect on IGF-I-induced AKT activation (Fig. 6a-c). In line with this result, both E2 and IGF-I increased the translocation of GLUT-4 at the plasma membrane (30 min) (Fig. 6d). In addition, cell pre-treatment with AKT inhibitor completely prevented both E2- and IGF-I-induced GLUT-4 translocation to the plasma membrane (Fig. 6e), confirming the pivotal role of this pathway in this event. Intriguingly, no change in GLUT-4 plasma membrane translocation was observed upon Nar stimulation, whereas, only in the presence of E2, Nar completely prevented AKT phosphorylation and GLUT-4 translocation (Fig. 6a, d), suggesting 

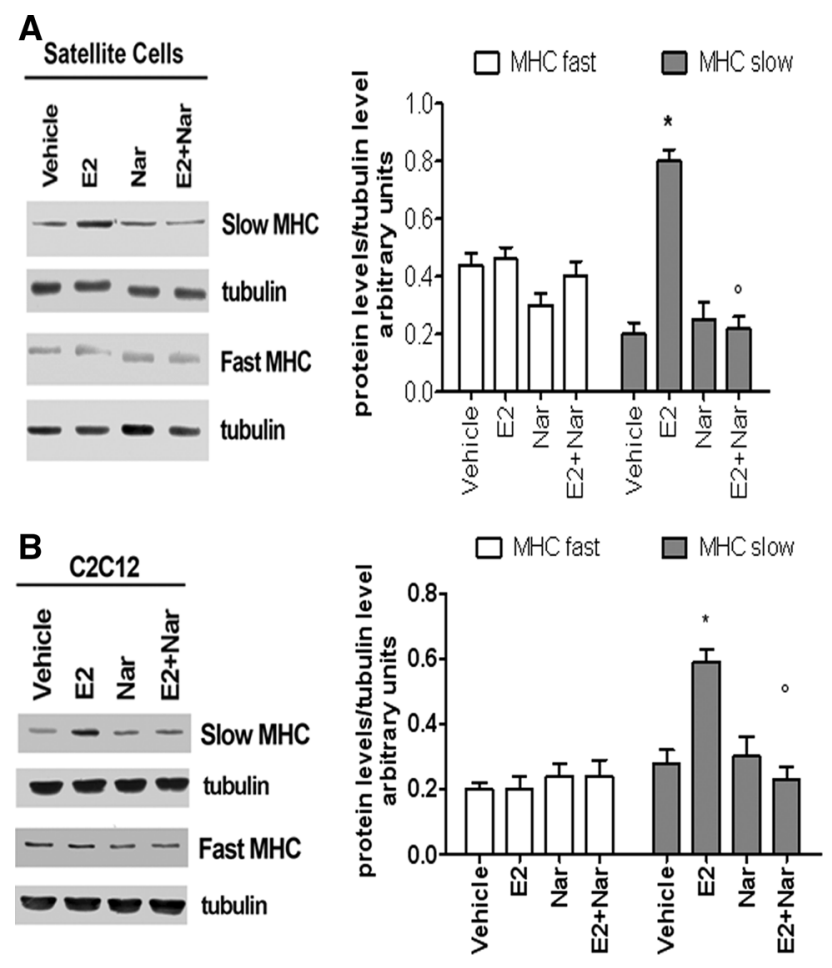

Fig. 4 Effect of E2 and Nar on slow and fast MHC level in satellite cells and in $\mathrm{C} 2 \mathrm{C} 12$ myoblasts. Typical Western blot and densitometric analyses of slow and fast MHC levels in satellite cells (a) and in $\mathrm{C} 2 \mathrm{C} 12$ myoblasts maintained in differentiation medium for $48 \mathrm{~h}$ in the presence of either vehicle (DMSO:PBS $0.1: 1)$ or E2 $\left(10^{-8} \mathrm{M}\right)$ or Nar $\left(10^{-6} \mathrm{M}\right)$. The amount of proteins was normalized by comparison with tubulin levels. Data represent the mean \pm SD of five experiments. $P<0.001$ was calculated with ANOVA followed by TukeyKramer post test with respect to vehicle-treated samples (asterisk) or to E2-treated samples (open circle)

that Nar specifically hampers ER $\alpha$-mediated AKT phosphorylation.

On the other hand, Nar activated, as well as E2, p38 phosphorylation even in the presence of E2 (Fig. 7a). L6 cell pre-treatment with the p38 inhibitor (SB 203580 $5 \mu \mathrm{M})$ prevented E2- and IGF-induced Myo and MHC increase (Fig. 7b), confirming the involvement of this kinase in E2- and IGF-induced Myo and MHC increase. However, the lack of Myo and MHC increase in Narstimulated cells indicate that p38 alone is not sufficient to lead L6 cell to differentiation. Indeed, AKT activation is also requested for the expression of these skeletal muscle differentiation markers as demonstrated by pre-treatment with AKT inhibitor (Fig. 7c). As consequence, Nar only impaired E2-induced Myo and MHC (Fig. 7d) levels in costimulation experiments, without affecting IGF-induced differentiation markers (Fig. 7d).

As a whole, these data demonstrate the specific ability of Nar to hamper E2-induced L6 cell differentiation by preventing the ER $\alpha$-mediated AKT phosphorylation.
Nar effect on ER $\beta$-mediated functions in L6 myoblasts

Reactive oxygen species (ROS) production physiologically occurs in resting and contracting muscle as well as during skeletal muscle differentiation as a by-product of mitochondrial respiration. However, when ROS levels overwhelm the endogenous antioxidant defense systems (Ji 2001), the resulting oxidative stress inhibits myoblast differentiation. P38 MAPK mediates oxidative stress-sensitive cell signaling pathways in several tissues including skeletal muscle (Powers et al. 2010). The evidence that both E2 and Nar, described as strong antioxidant (Tiidus et al. 2005), rapidly activates p38 prompted us to evaluate Nar effect, in comparison with $\mathrm{E} 2$, on $\mathrm{H}_{2} \mathrm{O}_{2}$-induced $\mathrm{ROS}$ production and the contribution of each ER isoform in mediating this putative effect. L6 cells were exposed to $\mathrm{H}_{2} \mathrm{O}_{2}(600 \mu \mathrm{M})$ for $15 \mathrm{~min}$, and then, ROS generation was measured (Fig. 8a). E2 (10 nM) or Nar $(1 \mu \mathrm{M})$ stimulation for $24 \mathrm{~h}$ before $\mathrm{H}_{2} \mathrm{O}_{2}$ addition caused a marked decrease in ROS generation (Fig. 8a). E2 antioxidant effects were completely mimicked by the ER $\beta$ selective agonists DPN, whereas the ER $\alpha$ selective agonist, PPT, was unable to prevent the ROS production (Fig. 8b). Moreover, the pure antagonists of ERs, ICI, and the ER $\beta$ selective antagonist, THC, completely prevented both E2- and Nar-induced decrease in ROS generation (Fig. 8b, c). These data suggest that, like E2, ER $\beta$ is involved in the Nar protective effect against $\mathrm{H}_{2} \mathrm{O}_{2}$-induced ROS production.

\section{Discussion}

In the present study, we report, for the first time, the ability of Nar to delay, without impeding, the differentiation of skeletal muscle cells preserving these cells from the cytotoxic effects of oxidative stress injury. The finding that $1 \mu \mathrm{M}$ Nar protects skeletal muscle against oxidative stress could be of importance even in humans as consumption of orange or grapefruit juice ( $8 \mathrm{ml} / \mathrm{kg}$ body weight) increases up to 0.6 or $6 \mu \mathrm{M}$, respectively, the plasma Nar levels (Erlund et al. 2001; Zygmunt et al. 2010). Thus, naringenin concentrations close to that could be reached in the plasma after a meal rich in citrus fruits (e.g., $1 \mu \mathrm{M})$ may play a significant role in skeletal muscle cells. Our results together with the recent observations that Nar can directly activate glucose uptake in cultured skeletal muscle (Zygmunt et al. 2010) as well as improve insulin action in skeletal muscle reduce plasma free fatty acid levels, and hepatic gluconeogenesis in fructose-fed insulin resistant rats (Kannappan and Anuradha 2010) sustains that skeletal muscle is a target tissue for this flavonoid. Conversely, contrasting effect of Nar on glucose transport in monocytes (Park 1999), in human breast cancer cells (Harmon and Patel 2004), and in 
Fig. 5 Long-term Effect of E2 and Nar on differentiation markers in L6 cells. Typical Western blot and densitometric analyses of myogenin, fetal and slow MHC levels in L6 cells (a) maintained in differentiation medium for 7 days in the presence of either vehicle (DMSO:PBS 0.1:1) or E2 $\left(10^{-8} \mathrm{M}\right)$ and/or Nar $\left(10^{-6} \mathrm{M}\right)$. The amount of proteins was normalized by comparison with tubulin levels. b Typical Western blot and densitometric analyses of fetal MHC levels in L6 cells in differentiation medium for 7 days in the presence of vehicle (DMSO:PBS 0.1:1) or E2 $\left(10^{-8} \mathrm{M}\right)$ or $\operatorname{Nar}\left(10^{-6} \mathrm{M}\right)$ and/or $10^{-6} \mathrm{M}$ ICI 182,780 (estrogen receptor inhibitor). Data represent the mean $\pm \mathrm{SD}$ of five experiments. $P<0.001$ was calculated with ANOVA followed by Tukey-Kramer post test with respect to vehicletreated samples (asterisk) or to E2-treated samples (open circle) or to Nar-treated samples (hash)
A

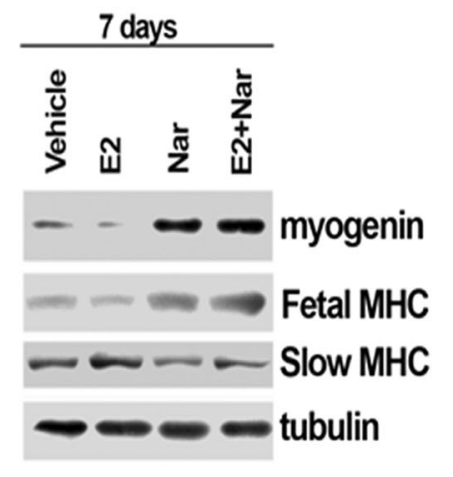

B

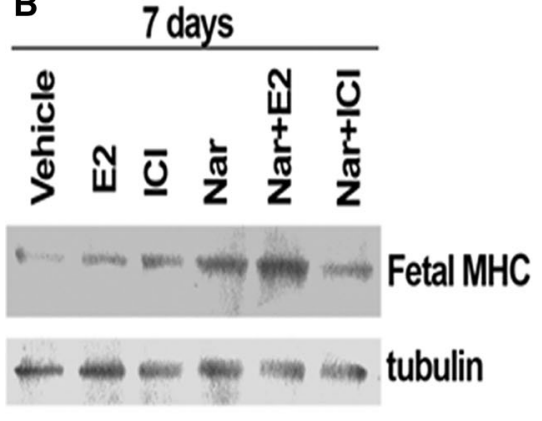

myogenin $\square$ fetal MHC $\square$ slow MHC
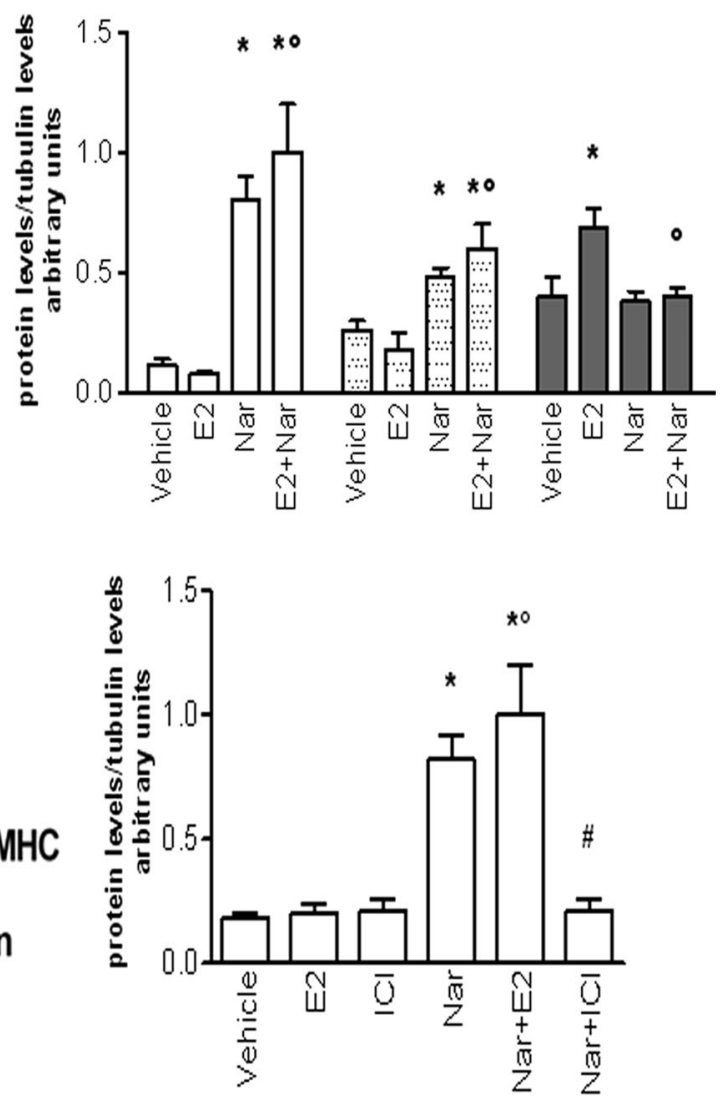

rat adipocytes (Harmon and Patel 2003) has been reported, suggesting a tissue-specific effect for this flavanone. However, these differences may be also due to the Nar concentration used, ranging from 1 to $100 \mu \mathrm{M}$, and/or to the cell lines used in each study, which could differently metabolize Nar and could be supplied with diverse receptor pattern including estrogen receptors. Indeed, like other flavonoids, Nar is well known as an estrogenic and antiestrogenic substance in dependence from the subtype of ER presents (Totta et al. 2004; Galluzzo et al. 2008; Kretzschmar et al. 2010; Amer et al. 2012; Swarnkar et al. 2012). In particular, our studies in cancer cells demonstrated that Nar hampers E2-related cancer cell progression by inhibiting the rapid $E R \alpha$-dependent signal transduction pathways important for E2-induced cancer cell cycle progression (Totta et al. 2004; Galluzzo et al. 2009). On the other hand, flavonoids act as E2 mimetic in the presence of ER $\beta$ subtype (Totta et al. 2004; Bulzomi et al. 2012). Whether similar action mechanisms are also activated by Nar in noncancerous cells is completely unknown. Skeletal muscle differentiation represents a good experimental model to reach this aim in that it has been established that rodent (Barros et al. 2006; Galluzzo et al. 2009) and human
(Lemoine et al. 2003; Wiik et al. 2003, 2009) skeletal muscles contain both functional ER subtypes.

Several studies indicate that E2 deficiency inhibits the muscle regeneration, and E2 supplementation enhances muscle mass and strength (Wust et al. 2008) accelerating skeletal muscles regeneration (McClung et al. 2006; Brown et al. 2005). In addition, previous data from our laboratory show the ability of E2 to increase the levels of well-known skeletal muscle differentiation (i.e., Myo and fetal MHC) and metabolic (i.e., GLUT-4 translocation) markers in growing L6 rat myoblasts (i.e., $10 \%$ serum) (Galluzzo et al. 2009). In good agreement with the literature (McClung et al. 2006; Brown et al. 2005; Thomas et al. 2010; Barros and Gustafsson 2011), this E2 effect is dependent on the receptor subtype $\alpha$ signaling initiating at the plasma membrane (Galluzzo et al. 2009), although the involvement of ER $\beta$ in the expression of satellite cell and muscle regeneration markers (i.e., MHC embryonic, MyoD, Pax7) after injury with a myotoxin (notexin) has been also reported (Velders et al. 2012). Here, we also confirm this E2 effect in differentiating conditions. In fact, E2, like IGF-I, rapidly increases both the activation of AKT, linked to muscle development, regeneration, and hypertrophy 
Fig. 6 Nar effect on AKT activation and GLUT-4 plasma membrane translocation. Typical Western blot and densitometric analyses of AKT phosphorylation (a, $\mathbf{b}$, and c) and GLUT-4 plasma membrane translocation (d and e) in L6 cells maintained in differentiation medium for $48 \mathrm{~h}$ and stimulated for $1 \mathrm{~h}(\mathbf{a}, \mathbf{b}$, and c) or $30 \mathrm{~min}$ (d and e) with either vehicle (DMSO:PBS $0.1: 1)$ or $\mathrm{E} 2\left(10^{-8} \mathrm{M}\right)$ or IGF (100 ng/ml) and/or Nar $\left(10^{-6} \mathrm{M}\right)$. When indicated cells have been pre-treated $(30 \mathrm{~min}$ ) with the AKT inhibitor $\left(10^{-6} \mathrm{M}\right)$. Data represent the mean $\pm \mathrm{SD}$ of five experiments. $P<0.001$ was calculated with ANOVA followed by Tukey-Kramer post test with respect to vehicletreated samples (asterisk) or to E2-treated samples (open circle)
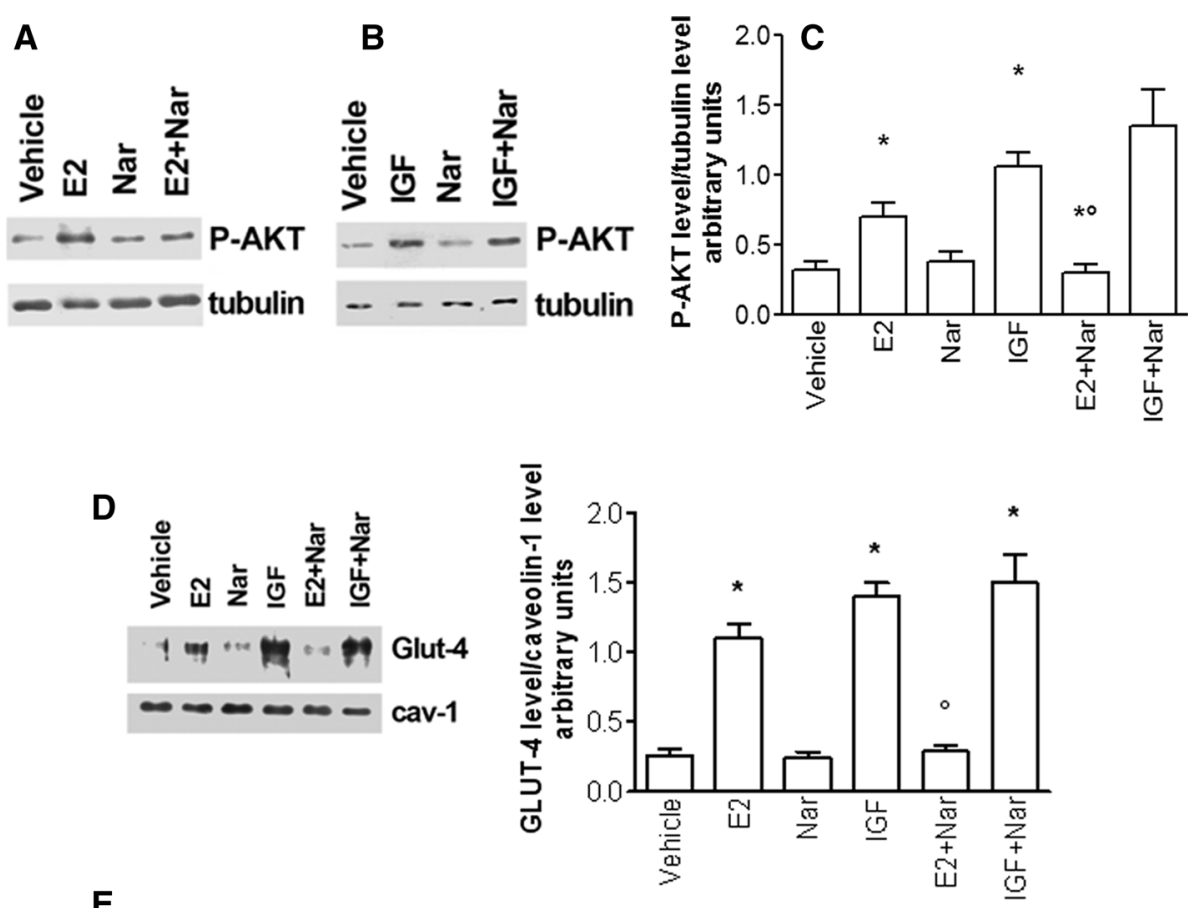

E

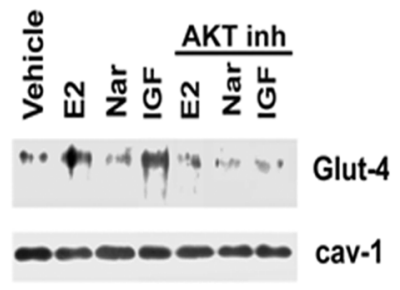

(Lawlor and Rotwein 2000; Rommel et al. 2001; Sandri et al. 2004) and the p38/MAPK signaling pathway, which is crucial for the transcriptional control of skeletal muscle differentiation and for the fusion of myoblasts into myotubes (Lluis et al. 2006). Although several studies suggest that the two pathways are parallel (Keren et al. 2006), present data demonstrate that p38 MAPK activation is not sufficient to enhance myoblast differentiation, highlighting the pivotal role of ER $\alpha$-activated AKT in promoting E2mediated myoblast differentiation.

Our results clearly indicate that Nar enhances Myo and fetal MHC levels only after long time of exposition (i.e., after 7 days), while Nar completely hampers E2 ability to induce myoblast and satellite cell differentiation. Notably, Nar does not prevent IGF-I-induced AKT activation, and in turn, it does not affect IGF-I-dependent differentiation.
These data strongly indicate that Nar, like in cancer cells (Totta et al. 2004; Galluzzo et al. 2008), specifically hampers ER $\alpha$-mediated AKT activation and its downstream pathways (i.e., GLUT-4 translocation, Myo and MHC expression) without any direct effect on the kinase activity. In line with these results, the intake of prenylated metabolite of Nar (8-prenyl naringenin), full agonist on ER $\alpha$ and pronounced antagonist on ER $\beta$ (Roelens et al. 2006), accelerates AKT phosphorylation preventing muscle atrophy, promoting post-natal growth, and delaying the degradation of skeletal muscles in denervated mice (Mukai et al. 2012). Intriguingly, no effect was reported by Nar intake on AKT activation and muscle recovery in the same mice (Mukai et al. 2012).

However, despite of its antagonistic effects on E2:ER $\alpha$ complex-mediated differentiation, Nar does not impair 
A 皆

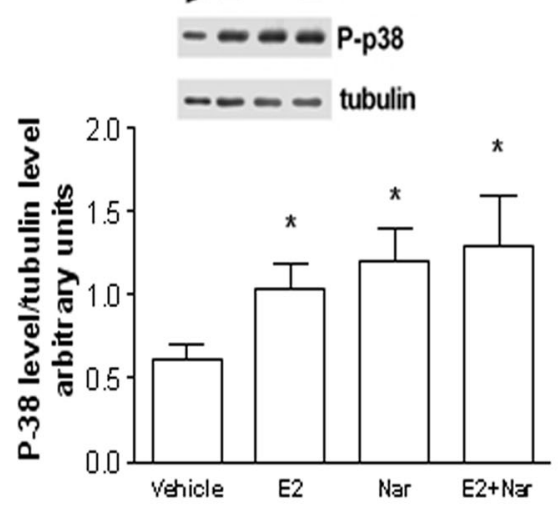

B
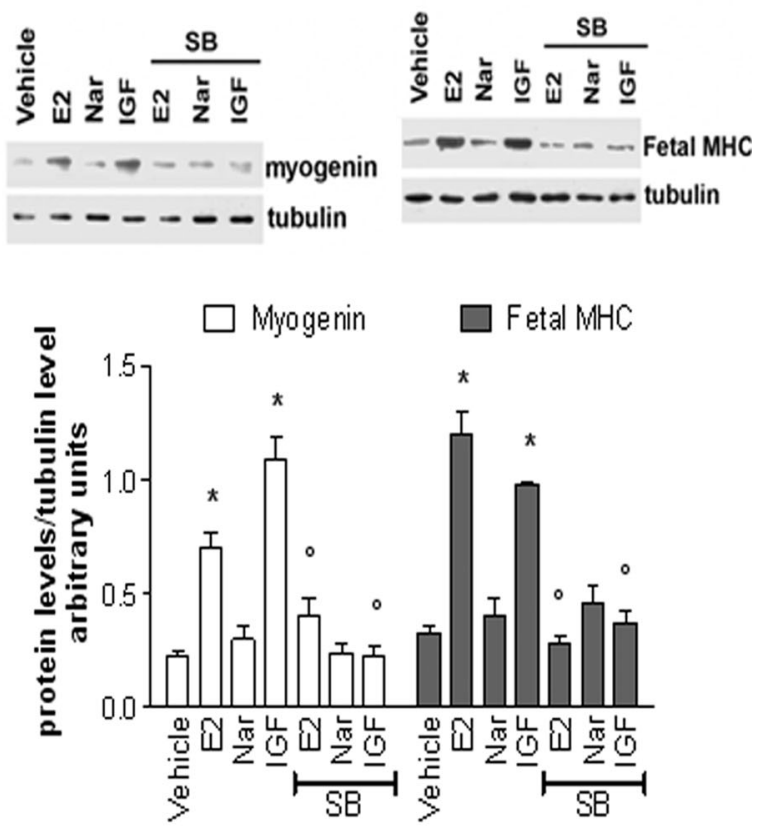

C

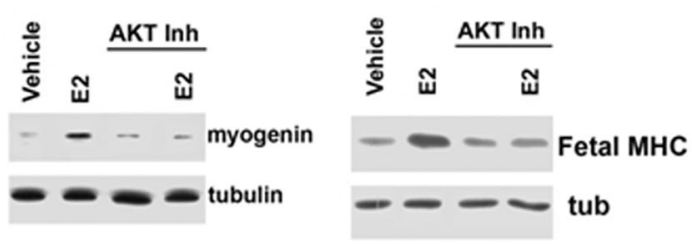

D
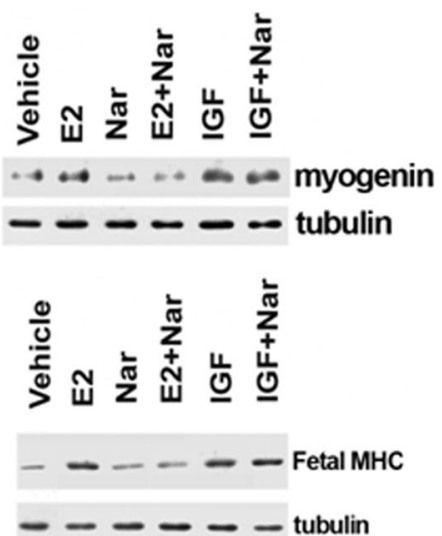

Fig. 7 Nar effect on p38 activation and myogenin and fetal MHC level. Typical Western blot and densitometric analyses of $\mathrm{p} 38$ phosphorylation (a), myogenin, and fetal MHC levels (b, c, and d) in L6 cells maintained in differentiation medium for $48 \mathrm{~h}$ and stimulated for $1 \mathrm{~h} \mathrm{(a)} \mathrm{or} 48 \mathrm{~h}$ (b, c, and d) with either vehicle (DMSO:PBS $0.1: 1)$ or E2 $\left(10^{-8} \mathrm{M}\right)$ or $\operatorname{IGF}(100 \mathrm{ng} / \mathrm{ml})$ and/or Nar $\left(10^{-6} \mathrm{M}\right)$. When
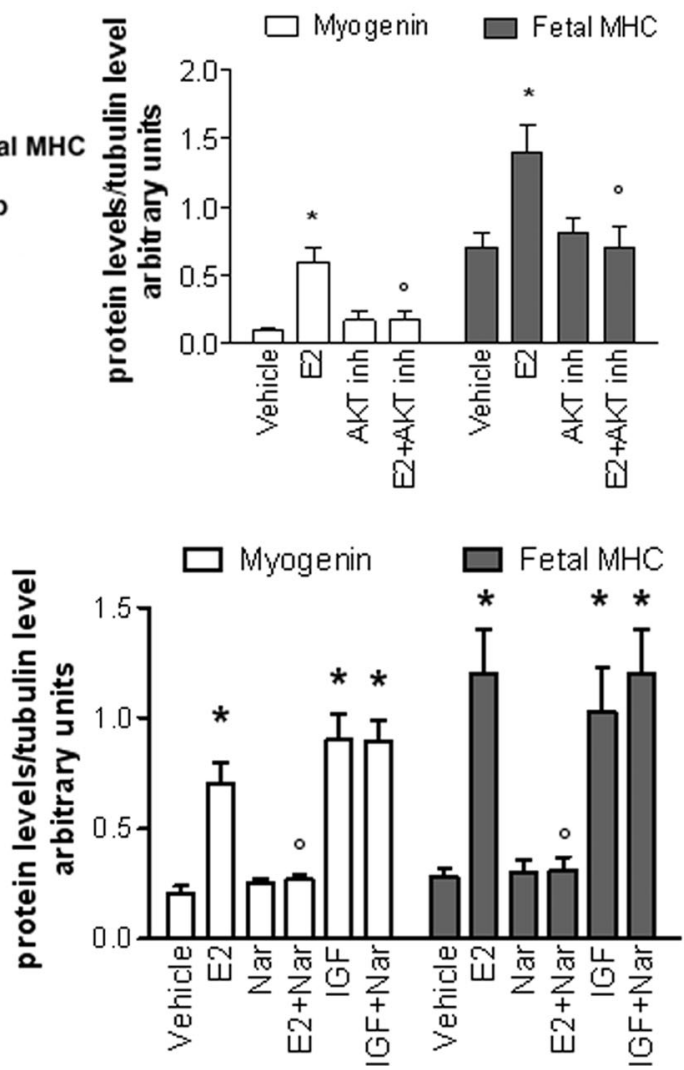

indicated cells have been pre-treated (20 min) with p38 inhibitor (SB, $\left.10^{-6} \mathrm{M}, \mathbf{b}\right)$ or with the AKT inhibitor $\left(10^{-6} \mathrm{M}, \mathbf{c}\right)$. Data represent the mean $\pm \mathrm{SD}$ of four experiments. $P<0.001$ was calculated with ANOVA followed by Tukey-Kramer post test with respect to vehicletreated samples (asterisk) or to E2-treated samples (open circle) 


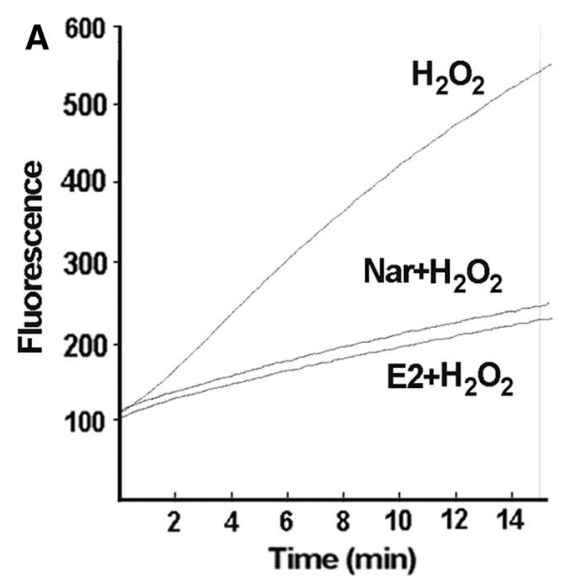

B

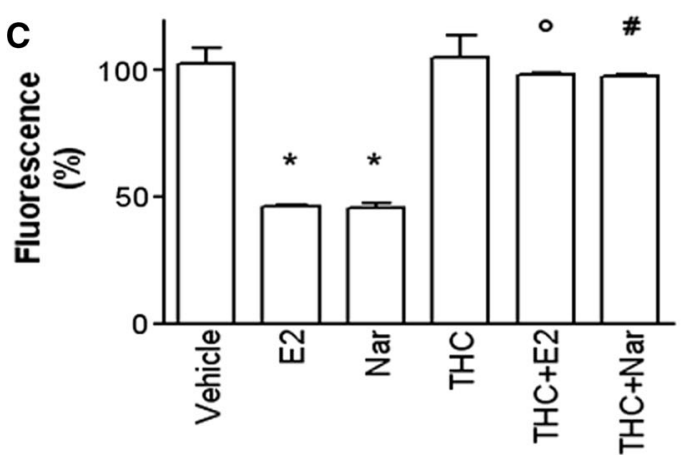

Fig. 8 Nar and E2 effect on $\mathrm{H}_{2} \mathrm{O}_{2}$-induced ROS production in L6 myoblasts. L6 cells, maintained in differentiation medium for $48 \mathrm{~h}$, were pre-treated, as indicated, with either vehicle (DMSO:PBS 0.1:1) or E2 $\left(10^{-8} \mathrm{M}\right)$ or Nar $\left(10^{-6} \mathrm{M}\right)$ or estrogen receptor inhibitor (ICI 182,780 , ICI, $10^{-6} \mathrm{M}$ ) or the ER $\alpha$ agonist (PPT, $\left.10^{-8} \mathrm{M}\right)$ or the ER $\beta$ agonist (DPN, $10^{-8} \mathrm{M}$ ) or the ER $\beta$ antagonist THC $\left(10^{-6} \mathrm{M}\right)$ before exposition to $\mathrm{H}_{2} \mathrm{O}_{2}\left(2 \times 10^{-4} \mathrm{M}\right)$ for $15 \mathrm{~min}$. In a typical original output (arbitrary units) of the registrations captured by the

muscle homeostasis and does not increase myoblast apoptosis. Our data demonstrate that Nar exerts a protective role on muscle, preventing ROS-induced damage. In muscle cells, ROS are continually generated. It is believed that these molecules have a well-established role as physiological modulators of skeletal muscle functions, including development, metabolism, and contractile functions. Moreover, studies in the past two decades suggest that, during strenuous muscle activity, in some pathological conditions or in aging, the generation of ROS in the skeletal muscle cells may be elevated to a level that overwhelms the antioxidant defense systems (Ji 1995, 2001) and can contribute to the development of muscle fatigue, inflammation, and degeneration (Meydani et al. 1992). When rat myoblasts were exposed to moderate or high intensity $\mathrm{H}_{2} \mathrm{O}_{2}$-induced oxidative stress for $1-6 \mathrm{~h}$, cell death induction became evident and the activation of the apoptotic pathway could be evaluated $2 \mathrm{~h}$ after treatment (Caporossi et al. 2003). Both E2 and Nar exert a protective effect on $\mathrm{H}_{2} \mathrm{O}_{2}$-induced ROS production via $\mathrm{ER} \beta$ activities.

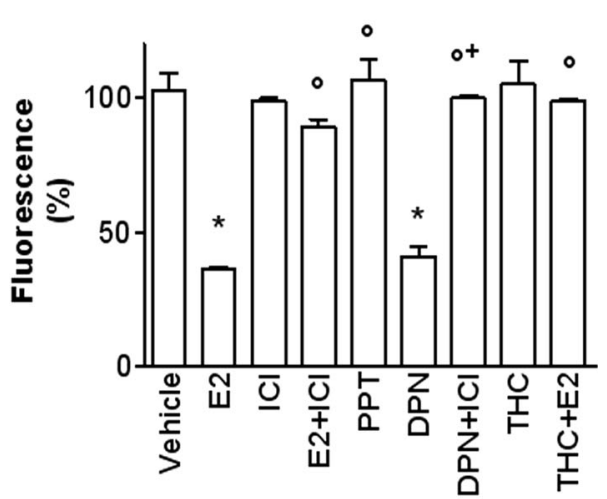

spectrofluorimeter during $15 \mathrm{~min}$ substance administration are reported. In $\mathbf{b}$ and $\mathbf{c}$ are reported data expressed as \% of variation between $\mathrm{H}_{2} \mathrm{O}_{2}$-stimulated fluorescence versus basal fluorescence for each stimulation. Data are the mean $\pm \mathrm{SD}$ of three experiments. $P<0.001$ was calculated with ANOVA followed by Tukey-Kramer post test with respect to vehicle-treated samples (asterisk) or to E2treated samples (open circle) or to DPN-treated samples (plus sign)or to Nar-treated samples (hash)

According to these data, E2:ER $\beta$ complex-mediated cytoprotection from oxidative stress has been reported also in ARPE cells (Giddabasappa et al. 2010). As a consequence, our data strongly support that Nar-mediated skeletal muscle protection from ROS-induced oxidative stress depends on its $\operatorname{ER} \beta$ agonist activity rather than a free radical quenching compound activity.

As a whole, data reported here strongly sustain that although Nar action mechanisms include the impairment of $\mathrm{ER} \alpha$ signals which drive muscle cells to differentiation, the protective effects triggered by Nar in the presence of ER $\beta$ could balance this negative effect avoiding the toxic effects produced by oxidative stress. Very recently, it has been reported that chronic exposition to naringin (the precursor of naringenin) for 6 months was well tolerated in SpragueDawley rats and did not cause either lethality or toxic clinical symptoms and changes in both sexes ( $\mathrm{Li}$ et al. 2014). The authors propose that the no-observed-adverseeffect level (NOAEL) of naringin could be greater than $1,250 \mathrm{mg} / \mathrm{kg} /$ day following daily oral administrations. 
Using the body surface area normalization method, authors define that the dose of $1,250 \mathrm{mg} / \mathrm{kg}$ naringin in rat corresponds to $12 \mathrm{~g} / 60 \mathrm{~kg}$ in humans (Li et al. 2014). Certainly, more experiments are needed to verify naringin and Nar effects in humans; in particular, the Nar bio-availability, the Nar concentration in the human blood that could be different in dependence on citrus-derived juices ingestion as daily or occasionally consumed, and the Nar metabolism that could produce active metabolites as already described for other flavonoids (Totta et al. 2005) are all necessary data to better define the effects of Nar on human health. Until then, our data obtained in cultured skeletal muscle cells open a new field of investigation indicating the role of Nar in the modulation of skeletal muscle differentiation.

Acknowledgments Authors whish to thank Dr. M. Crescenzi (Department of Environment and Primary Prevention, Istituto Superiore di Sanità, Viale Regina Elena 299, 00161 Rome, Italy) and Prof. Daniela Caporossi (University of Rome "Foro Italico", Piazza L. de Bosis 6, 00135, Rome, Italy) for Satellite cells and C2C12 myoblasts, respectively. This work was supported by grants from the University Roma Tre (to M.M.).

\section{References}

Amer DA, Jahne M, Weigt C, Kretzschmar G, Vollmer G (2012) Effect of 17beta-estradiol and flavonoids on the regulation of expression of newly identified oestrogen responsive genes in a rat raphe nuclei-derived cell line. J Cell Physiol 227:3434-3445

Arul D, Subramanian P (2013) Naringenin (citrus flavonone) induces growth inhibition, cell cycle arrest and apoptosis in human hepatocellular carcinoma cells. Pathol Oncol Res 19:763-770

Bar PR, Amelink GJ, Oldenburg B, Blankenstein MA (1988) Prevention of exercise-induced muscle membrane damage by oestradiol. Life Sci 42:2677-2681

Barros RP, Machado UF, Warner M, Gustafsson JA (2006) Muscle GLUT4 regulation by estrogen receptors ER $\beta$ and ER $\alpha$. Proc Natl Acad Sci USA 103:1605-1608

Barros RP, Gustafsson JA (2011) Estrogen receptors and the metabolic network. Cell Metab 14:289-299

Bengmark S, Mesa MD, Gil A (2009) Plant-derived health: the effects of turmeric and curcuminoids. Nutr Hosp 24:273-281

Brown M, Foley A, Ferreria JA (2005) Ovariectomy, hindlimb unweighting, and recovery effects on skeletal muscle in adult rats. Aviat Space Environ Med 76:1012-1018

Bulzomi P, Bolli A, Galluzzo P, Leone S, Acconcia F, Marino M (2010) Naringenin and 17beta-estradiol coadministration prevents hormone-induced human cancer cell growth. IUBMB Life 62:51-60

Bulzomi P, Galluzzo P, Bolli A, Leone S, Acconcia F, Marino M (2012) The pro-apoptotic effect of quercetin in cancer cell lines requires ERbeta-dependent signals. J Cell Physiol 227:1891-1898

Caporossi D, Ciafre SA, Pittaluga M, Savini I, Farace MG (2003) Cellular responses to $\mathrm{H}(2) \mathrm{O}(2)$ and bleomycin-induced oxidative stress in L6C5 rat myoblasts. Free Radic Biol Med 35:1355-1364

Ciciliot S, Schiaffino S (2010) Regeneration of mammalian skeletal muscle. Basic mechanisms and clinical implications. Curr Pharm Des 16:906-914
Crozier A, Jaganath IB, Clifford MN (2009) Dietary phenolics: chemistry, bioavailability and effects on health. Nat Prod Rep 26:1001-1043

Erlund I, Meririnne E, Alfthan G, Aro A (2001) Plasma kinetics and urinary excretion of the flavanones naringenin and hesperetin in humans after ingestion of orange juice and grapefruit juice. J Nutr 131:235-241

Galluzzo P, Marino M (2006) Nutritional flavonoids impact on nuclear and extranuclear estrogen receptor activities. Genes Nutr $1: 161-176$

Galluzzo P, Ascenzi P, Bulzomi P, Marino M (2008) The nutritional flavanone naringenin triggers antiestrogenic effects by regulating estrogen receptor alpha-palmitoylation. Endocrinology 149: 2567-2575

Galluzzo P, Rastelli C, Bulzomi P, Acconcia F, Pallottini V, Marino M (2009) 17beta-Estradiol regulates the first steps of skeletal muscle cell differentiation via ER-alpha-mediated signals. Am J Physiol Cell Physiol 297:C1249-C1262

Giddabasappa A, Bauler M, Yepuru M, Chaum E, Dalton JT, Eswaraka J (2010) 17-beta estradiol protects ARPE-19 cells from oxidative stress through estrogen receptor-beta. Invest Ophthalmol Vis Sci 51:5278-5287

Harmon AW, Patel YM (2003) Naringenin inhibits phosphoinositide 3-kinase activity and glucose uptake in 3T3-L1 adipocytes. Biochem Biophys Res Commun 305:229-234

Harmon AW, Patel YM (2004) Naringenin inhibits glucose uptake in MCF-7 breast cancer cells: a mechanism for impaired cellular proliferation. Breast Cancer Res Treat 85:103-110

Hawke TJ, Garry DJ (2001) Myogenic satellite cells: physiology to molecular biology (1985). J Appl Physiol 91:534-551

Huong DT, Takahashi Y, Ide T (2006) Activity and mRNA levels of enzymes involved in hepatic fatty acid oxidation in mice fed citrus flavonoids. Nutrition 22:546-552

Jeon SM, Kim HK, Kim HJ, Do GM, Jeong TS, Park YB, Choi MS (2007) Hypocholesterolemic and antioxidative effects of naringenin and its two metabolites in high-cholesterol fed rats. Transl Res 149:15-21

Ji LL (1995) Oxidative stress during exercise: implication of antioxidant nutrients. Free Radic Biol Med 18:1079-1086

Ji LL (2001) Exercise at old age: does it increase or alleviate oxidative stress? Ann N Y Acad Sci 928:236-247

Jung UJ, Lee MK, Jeong KS, Choi MS (2004) The hypoglycemic effects of hesperidin and naringin are partly mediated by hepatic glucose-regulating enzymes in C57BL/KsJ-db/db mice. J Nutr 134:2499-2503

Kannappan S, Anuradha CV (2010) Naringenin enhances insulinstimulated tyrosine phosphorylation and improves the cellular actions of insulin in a dietary model of metabolic syndrome. Eur J Nutr 49:101-109

Keren A, Tamir Y, Bengal E (2006) The p38 MAPK signaling pathway: a major regulator of skeletal muscle development. Mol Cell Endocrinol 252:224-230

Kretzschmar G, Zierau O, Wober J, Tischer S, Metz P, Vollmer G (2010) Prenylation has a compound specific effect on the estrogenicity of naringenin and genistein. J Steroid Biochem Mol Biol 118:1-6

Kuiper GG, Lemmen JG, Carlsson B, Corton JC, Safe SH, van der Saag PT, van der Burg B, Gustafsson JA (1998) Interaction of estrogenic chemicals and phytoestrogens with estrogen receptor beta. Endocrinology 139:4252-4263

Lawlor MA, Rotwein P (2000) Insulin-like growth factor-mediated muscle cell survival: central roles for Akt and cyclin-dependent kinase inhibitor p21. Mol Cell Biol 20:8983-8995

Lemoine S, Granier P, Tiffoche C, Rannou-Bekono F, Thieulant ML, Delamarche P (2003) Estrogen receptor $\alpha$ mRNA in human skeletal muscles. Med Sci Sports Exerc 35:439-443 
Li P, Wang S, Guan X, Cen X, Hu C, Peng W, Wang Y, Su W (2014) Six months chronic toxicological evaluation of naringin in Sprague-Dawley rats. Food Chem Toxicol 66:65-75

Lluis F, Perdiguero E, Nebreda AR, Munoz-Canoves P (2006) Regulation of skeletal muscle gene expression by p38 MAP kinases. Trends Cell Biol 16:36-44

Marino M, Pellegrini M, La Rosa P, Acconcia F (2012) Susceptibility of estrogen receptor rapid responses to xenoestrogens: physiological outcomes. Steroids 77:910-917

McClung JM, Davis JM, Wilson MA, Goldsmith EC, Carson JA (2006) Estrogen status and skeletal muscle recovery from disuse atrophy (1985). J Appl Physiol 100:2012-2023

Meiyanto E, Hermawan A, Anindyajati A (2012) Natural products for cancer-targeted therapy: citrus flavonoids as potent chemopreventive agents. Asian Pac J Cancer Prev 13:427-436

Meydani M, Evans W, Handelman G, Fielding RA, Meydani SN, Fiatarone MA, Blumberg JB, Cannon JG (1992) Antioxidant response to exercise-induced oxidative stress and protection by vitamin E. Ann N Y Acad Sci 669:363-364

Mukai R, Horikawa H, Fujikura Y, Kawamura T, Nemoto H, Nikawa T, Terao J (2012) Prevention of disuse muscle atrophy by dietary ingestion of 8-prenylnaringenin in denervated mice. PLoS One 7:e45048

Park JB (1999) Flavonoids are potential inhibitors of glucose uptake in U937 cells. Biochem Biophys Res Commun 260:568-574

Powers SK, Duarte J, Kavazis AN, Talbert EE (2010) Reactive oxygen species are signalling molecules for skeletal muscle adaptation. Exp Physiol 95:1-9

Renugadevi J, Prabu SM (2009) Naringenin protects against cadmium-induced oxidative renal dysfunction in rats. Toxicology 256:128-134

Roelens F, Heldring N, Dhooge W, Bengtsson M, Comhaire F, Gustafsson JA, Treuter E, De Keukeleire D (2006) Subtle sidechain modifications of the hop phytoestrogen 8-prenylnaringenin result in distinct agonist/antagonist activity profiles for estrogen receptors alpha and beta. J Med Chem 49:7357-7365

Rommel C, Bodine SC, Clarke BA, Rossman R, Nunez L, Stitt TN, Yancopoulos GD, Glass DJ (2001) Mediation of IGF-1-induced skeletal myotube hypertrophy by $\mathrm{PI}(3) \mathrm{K} / \mathrm{Akt} / \mathrm{mTOR}$ and $\mathrm{PI}(3) \mathrm{K} /$ Akt/GSK3 pathways. Nat Cell Biol 3:1009-1013

Sandri M, Sandri C, Gilbert A, Skurk C, Calabria E, Picard A, Walsh K, Schiaffino S, Lecker SH, Goldberg AL (2004) Foxo transcription factors induce the atrophy-related ubiquitin ligase atrogin-1 and cause skeletal muscle atrophy. Cell 117:399-412

Shulman M, Cohen M, Soto-Gutierrez A, Yagi H, Wang H, Goldwasser J, Lee-Parsons CW, Benny-Ratsaby O, Yarmush ML, Nahmias Y (2011) Enhancement of naringenin bioavailability by complexation with hydroxypropyl-beta-cyclodextrin [corrected]. PLoS One 6:e18033

Swarnkar G, Sharan K, Siddiqui JA, Mishra JS, Khan K, Khan MP, Gupta V, Rawat P, Maurya R, Dwivedi AK, Sanyal S,
Chattopadhyay N (2012) A naturally occurring naringenin derivative exerts potent bone anabolic effects by mimicking oestrogen action on osteoblasts. Br J Pharmacol 165:1526-1542

Thomas C, Gustafsson JA (2011) The different roles of ER subtypes in cancer biology and therapy. Nat Rev Cancer 11:597-608

Thomas A, Bunyan K, Tiidus PM (2010) Oestrogen receptor-alpha activation augments post-exercise myoblast proliferation. Acta Physiol (Oxf) 198:81-89

Tiidus PM, Deller M, Liu XL (2005) Oestrogen influence on myogenic satellite cells following downhill running in male rats: a preliminary study. Acta Physiol Scand 184:67-72

Totta P, Acconcia F, Leone S, Cardillo I, Marino M (2004) Mechanisms of naringenin-induced apoptotic cascade in cancer cells: involvement of estrogen receptor alpha and beta signalling. IUBMB Life 56:491-499

Totta P, Acconcia F, Virgili F, Cassidy A, Weinberg PD, Rimbach G, Marino M (2005) Daidzein-sulfate metabolites affect transcriptional and antiproliferative activities of estrogen receptor-beta in cultured human cancer cells. J Nutr 135:2687-2693

Trapani L, Segatto M, La Rosa P, Fanelli F, Moreno S, Marino M, Pallottini V (2012) 3-hydroxy 3-methylglutaryl coenzyme A reductase inhibition impairs muscle regeneration. J Cell Biochem 113:2057-2063

Velders M, Schleipen B, Fritzemeier KH, Zierau O, Diel P (2012) Selective estrogen receptor-beta activation stimulates skeletal muscle growth and regeneration. FASEB J 26:1909-1920

Virgili F, Acconcia F, Ambra R, Rinna A, Totta P, Marino M (2004) Nutritional flavonoids modulate estrogen receptor alpha signaling. IUBMB Life 56:145-151

Weng CJ, Yen GC (2012) Flavonoids, a ubiquitous dietary phenolic subclass, exert extensive in vitro anti-invasive and in vivo antimetastatic activities. Cancer Metastasis Rev 31:323-351

Wiik A, Glenmark B, Ekman M, Esbjörnsson-Liljedahl M, Johansson O, Bodin K, Enmark E, Jansson E (2003) Oestrogen receptor beta is expressed in adult human skeletal muscle both at the mRNA and protein level. Acta Physiol Scand 179:381-387

Wiik A, Hellsten Y, Berthelson P, Lundholm L, Fischer H, Jansson E (2009) Activation of estrogen response elements is mediated both via estrogen and muscle contractions in rat skeletal muscle myotubes. Am J Physiol Cell Physiol 296:C215-C220

Wust RC, Morse CI, de Haan A, Jones DA, Degens H (2008) Sex differences in contractile properties and fatigue resistance of human skeletal muscle. Exp Physiol 93:843-850

Zammit PS, Partridge TA, Yablonka-Reuveni Z (2006) The skeletal muscle satellite cell: the stem cell that came in from the cold. J Histochem Cytochem 54:1177-1191

Zygmunt K, Faubert B, MacNeil J, Tsiani E (2010) Naringenin, a citrus flavonoid, increases muscle cell glucose uptake via AMPK. Biochem Biophys Res Commun 398:178-183 